\title{
Efficient and Low-Cost Removal of Methylene Blue using Activated Natural Kaolinite Material
}

Christyowati Primi Sagita, Limpat Nulandaya, and Yehezkiel Steven Kurniawan*

\begin{tabular}{|c|c|c|c|}
\hline Received : February 19, 2021 & Revised : March 23, 2021 & Accepted : April 15, 2021 & Online : April 17, 2021 \\
\hline \multicolumn{4}{|c|}{$\begin{array}{l}\text { Abstract } \\
\text { Clays are low-price and very useful material for water treatment purpose. In this work, we reported the application of activated } \\
\text { natural kaolinite material which obtained from Wediombo beach, Yogyakarta for methylene blue adsorption. The natural kaolinite } \\
\text { material was activated under an acidic condition to obtain the activated kaolinite material. The activated kaolinite material was } \\
\text { characterized using Fourier transform infrared, X-ray diffraction, scanning electron microscope, and surface analysis. From the } \\
\text { adsorption experiment, the activated kaolinite material gave moderate adsorption percentages for methylene blue. The adsorption } \\
\text { kinetics followed the Ho and McKay kinetic model while the adsorption isotherm followed Langmuir model. The q } \text { quax }_{\text {malue for }} \text { value } \\
\text { methylene blue adsorption using activated natural kaolinite material was at a moderate level }\left(3.40 \mathrm{mg} \mathrm{g}^{-1}\right) \text {. The plausible adsorption } \\
\text { mechanism of methylene blue on the surface of activated kaolinite material happened through hydrogen bondings and/or electro- } \\
\text { static interactions. These findings are important for a wastewater treatment using a low-cost adsorbent material. }\end{array}$} \\
\hline
\end{tabular}

\section{INTRODUCTION}

Water pollution has reached alarming levels nowadays thus there is no option to neglect pollutant removal issue [1][2]. Among the harmful water pollutants, synthetic dyes are the most stable chemicals in the aquatic environment. Their stability is a very serious issue because it means their degradation process may take a very long period thus heightens the possibility to spread out and reach our food chain [3]. Methylene blue is a synthetic sulfur- and nitrogen-heterocyclic compound that widely used for textile and dye applications in our life. Unfortunately, methylene blue is a very toxic chemical for human health because it generates headache, nausea, skin irritation, respiratory infection and nervous disruption [4][5]. Because of that, effort on the removal of methylene blue shall be carefully considered.

Adsorption is the simplest removal technique of

\section{Copyright Holder:}

(C) Sagita, C. P., Nulandaya, L., and Kurniawan, Y. S. (2021)

First Publication Right:

Journal of Multidisciplinary Applied Natural Science

Publisher's Note:

Pandawa Institute stays neutral with regard to jurisdictional claims in published maps and institutional affiliations.

This Article is Licensed Under: methylene blue at room temperature and ambient pressure [6]. Hundreds of adsorbent materials have been designed and investigated for methylene blue removal, however, some of the adsorbent materials are expensive and they need a complicated preparation [7]-[12]. Clay materials are low-cost adsorbent materials because they are naturally abundant in Indonesia [13][14]. Activated montmorillonite and bentonite materials showed remarkable adsorption capability for methylene blue removal from the aqueous phase [15]-[17]. It was reported that natural kaolinite clay material was found at Wediombo beach, Yogyakarta [18], however, their application for methylene blue adsorption has not been reported yet. Therefore, an effort on the utilization of natural kaolinite material for an environmental remediation process is challenging for the researcher.

In the present work, we evaluated the application of activated kaolinite for methylene blue removal from the aqueous solution. The activated kaolinite material was characterized using Fourier transform infrared, X-ray diffraction, scanning electron microscope, and surface analysis. The adsorption kinetics and isotherm adsorption experiments of methylene blue adsorption using activated kaolinite materials will be discussed.

\section{MATERIALS AND METHODS}

\subsection{Materials}

Kaolinite material from Wediombo beach and 


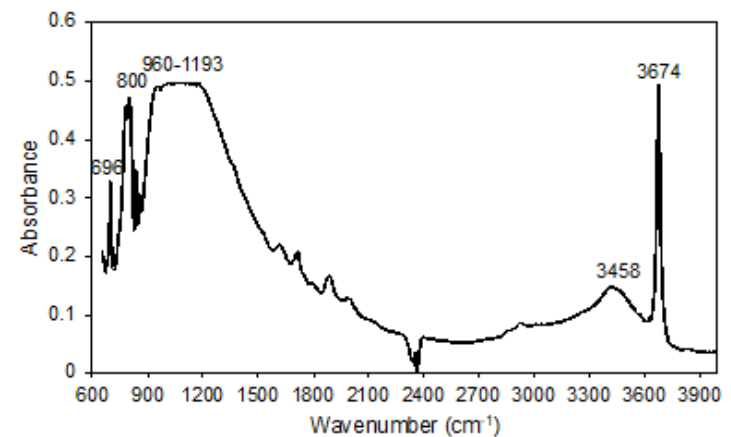

(a)

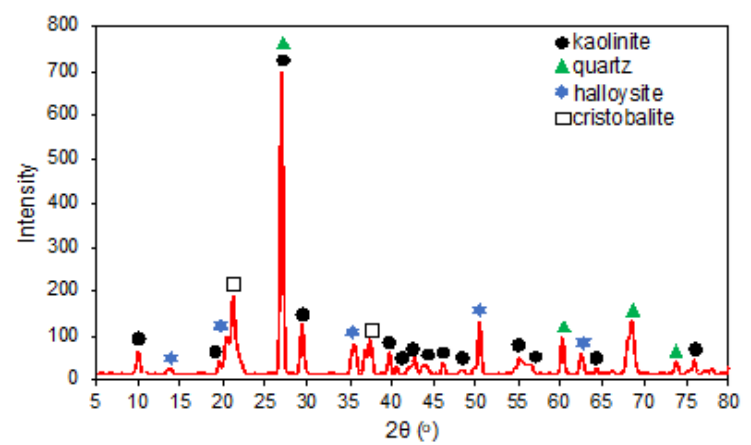

(b)

Figure 1. (a) FTIR spectrum and (b) XRD pattern of activated kaolinite material.

distilled water were purchased from Progo chemical distributor while methylene blue and concentrated sulfuric acid (98\%) was purchased from Merck in pro analytical grade.

\subsection{Instruments}

The Fourier transform infrared (FTIR) of the material was measured by a Shimadzu IR Prestige21 spectrophotometer while the morphological image of the material was recorded using a scanning electron microscope (SEM) JEOL JSM6510. The X-ray diffractogram of the material was obtained using Shimadzu XRD S-6000. The surface analysis of the material was examined through a nitrogen adsorption-desorption method using a Quantachrome Nova station A apparatus. The concentration of methylene blue in the aqueous solution was measured from a standard curve with several concentration series $(5,10,20$, and 30 $\mathrm{mg} \mathrm{L}^{-1}$ ) using a double beam Shimadzu UV-Vis spectrophotometer UV-1800.

\subsection{Methods}

\subsubsection{Activation of Kaolinite}

Activation of kaolinite material was carried out in a similar procedure previously reported by Kurniawan et al. [19]. Briefly, as much as $10 \mathrm{~g}$ of raw kaolinite material was added into $100 \mathrm{~mL}$ sulfuric acid 1.0 M. The mixture was refluxed at $350 \mathrm{~K}$ for $6 \mathrm{~h}$. After the reaction, the mixture was filtrated and the residue was washed until neutral. The residue was dried at $330 \mathrm{~K}$ and characterized by FTIR, XRD, SEM, and surface analysis.

\subsubsection{Adsorption of methylene blue}

Methylene blue solution was prepared by dissolving $20 \mathrm{mg}$ of methylene blue in $1 \mathrm{~L}$ of distilled water to obtain a concentration of $20 \mathrm{mg} \mathrm{L}^{-}$ 1. As much as $200 \mathrm{mg}$ of kaolinite material was added into $50 \mathrm{~mL}$ of methylene blue solution and then the mixture was stirred at $150 \mathrm{rpm}$. The concentration of methylene blue was measured using a UV-Vis spectrophotometer. The adsorption kinetic study was conducted by varying the adsorption time form $50 \mathrm{~mL}$ of methylene blue 20 $\mathrm{mg} \mathrm{L}^{-1}$ with $10 \mathrm{mg}$ adsorbent material. Meanwhile, the adsorption isotherm study was evaluated by varying the methylene blue concentration as the aqueous solution.

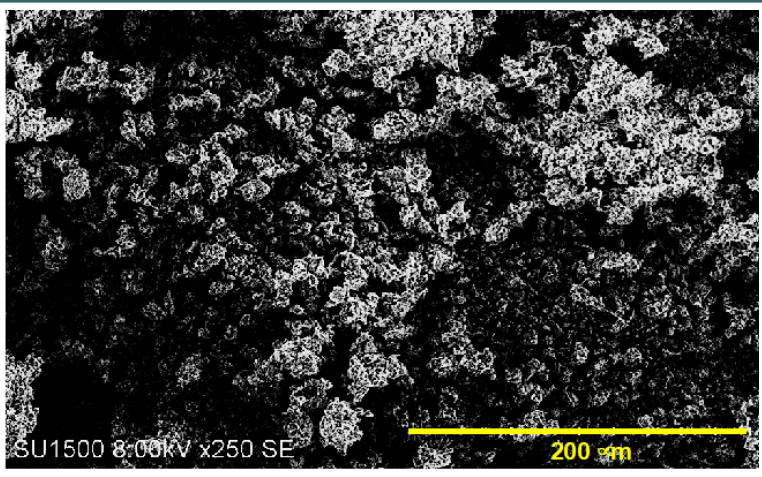

(a)

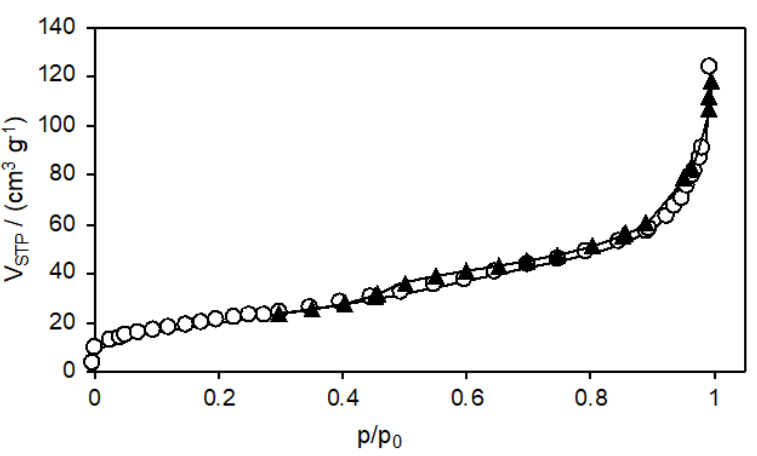

(b)

Figure 2. (a) SEM micrograph and (b) nitrogen adsorption-desorption isotherm plot of activated kaolinite material. 

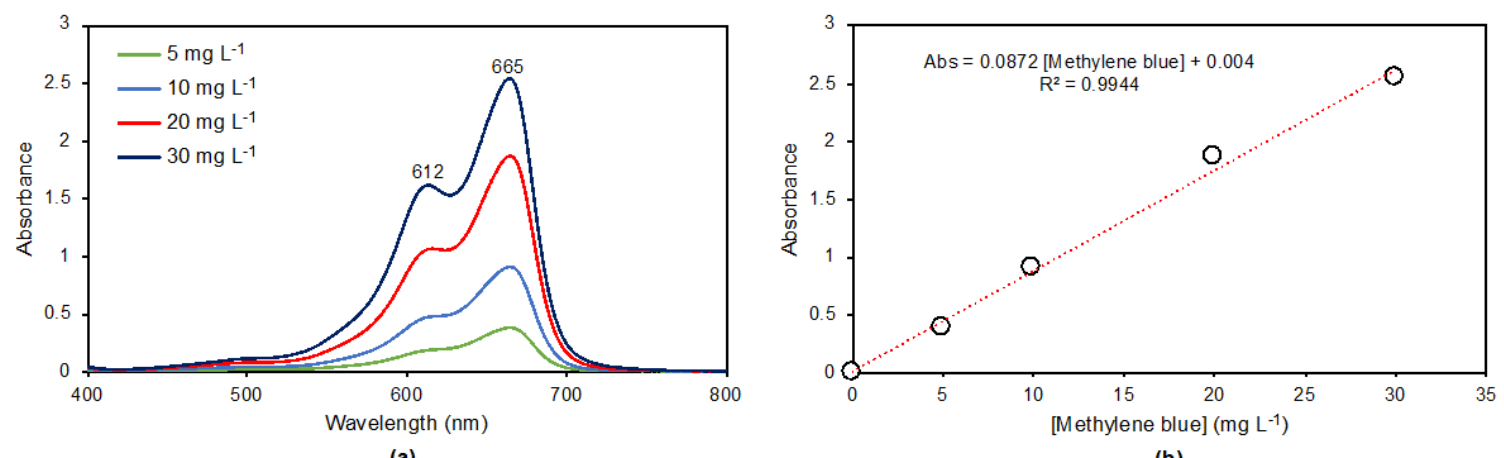

(b)

Figure 3. (a) Visible spectra and (b) calibration curve of methylene blue standard solution.

\section{RESULTS AND DISCUSSIONS}

\subsection{Activation of kaolinite}

Acidic activation of kaolinite material was carried out to remove the impurities from its threedimensional structure [20]. The common impurities of clay materials are base metal ions that interacted with the tetrahedral silica and octahedral alumina framework through electrostatic interaction. The success of the activation process was elucidated using the FTIR spectroscopy. Figure 1(a) shows the FTIR spectrum of the activated kaolinite material from $600-4,000 \mathrm{~cm}^{-1}$. It was found that the O-Si-O bending and Si-O stretching signals at 696 and 800 $\mathrm{cm}^{-1}$ appeared as a sharp signal. The $\mathrm{AlO}_{6}$ and $\mathrm{SiO}_{4}$ absorption signals appeared as a broad signal at 960 $-1,193 \mathrm{~cm}^{-1}$. While the $\mathrm{O}-\mathrm{H}$ and $\mathrm{AlO}-\mathrm{H}$ functional groups are appeared as a broad signal at $3,458 \mathrm{~cm}^{-1}$ and a sharp signal at $3,674 \mathrm{~cm}^{-1}$, respectively. These spectral characteristics were similar to the other reported literature thus proving that the activation of kaolinite material was successfully carried out [21][22].
The XRD pattern of activated kaolinite is displayed in Figure 1(b). Since the kaolinite material was obtained from Wediombo beach thus the several crystalline phases were found such as kaolinite (JCPDS 00-005-0143), quartz (JCPDS 00046-1045), halloysite (JCPDS 00-029-1487), and cristobalite (JCPDS 00-039-1425). The diffractogram signals at $2 \theta=10.06,19.46,26.96$, $29.42,39.82,40.76,42.78,43.92,46.20,48.44$, $55.30,56.56,63.48$, and 75.80 correspond to the kaolinite crystal phase with hkl plane of $\left(\begin{array}{lll}0 & 0 & 1\end{array}\right),\left(\begin{array}{ll}0 \\ 0\end{array}\right.$ $20),\left(\begin{array}{lll}1 & 1 & 1\end{array}\right),\left(\begin{array}{lll}-1 & 1 & 2\end{array}\right),\left(\begin{array}{lll}0 & 1 & 3\end{array}\right),\left(\begin{array}{lll}-1 & -3 & 2\end{array}\right),\left(\begin{array}{lll}-1 & -2 & 3\end{array}\right),(-2$ 2 2), (-2 13 3), (1 $\left.4 \begin{array}{ll}1 & 1\end{array}\right),\left(\begin{array}{lll}3 & 0 & 0\end{array}\right),\left(\begin{array}{lll}-1 & 4 & 3\end{array}\right),\left(\begin{array}{lll}-2 & 5 & 1\end{array}\right)$, and $(-2-62)$, respectively. The diffractogram signals at $2 \theta=26.96,60.32,68.40$, and 73.78 correspond to the quartz crystal phase with (lll 01 ), ( $\left.\begin{array}{lll}2 & 1 & 1\end{array}\right),\left(\begin{array}{ll}3 & 0\end{array}\right.$ $1)$, and ( $\left(\begin{array}{lll}1 & 0 & 4\end{array}\right)$ hkl planes, respectively. The diffractogram signals at $2 \theta=13.66,20.06,35.15$, 54.27, and 62.64 correspond to the halloysite crystal phase with hkl plane of (llll $\left.0 \begin{array}{lll}0 & 1\end{array}\right),\left(\begin{array}{lll}1 & 0 & 0\end{array}\right),\left(\begin{array}{ll}1 & 1\end{array}\right.$ 0), (2 10$)$, and (3 00$)$, respectively. Meanwhile, the diffractogram signals at $2 \theta=21.98$ and 36.56 correspond to the cristobalite crystal phase with $(1$

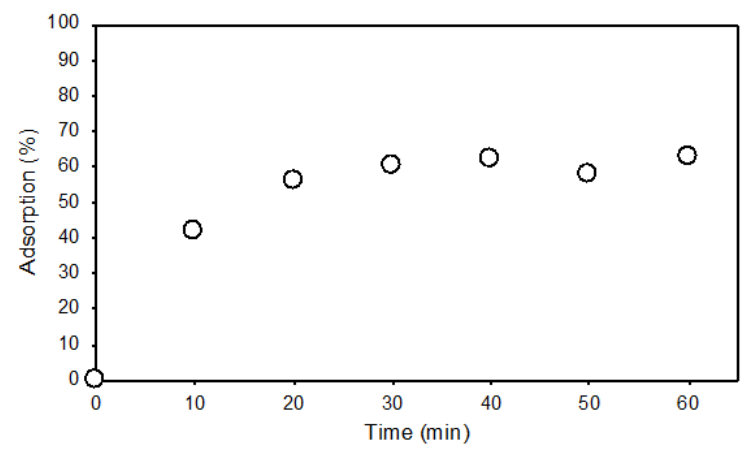

(a)

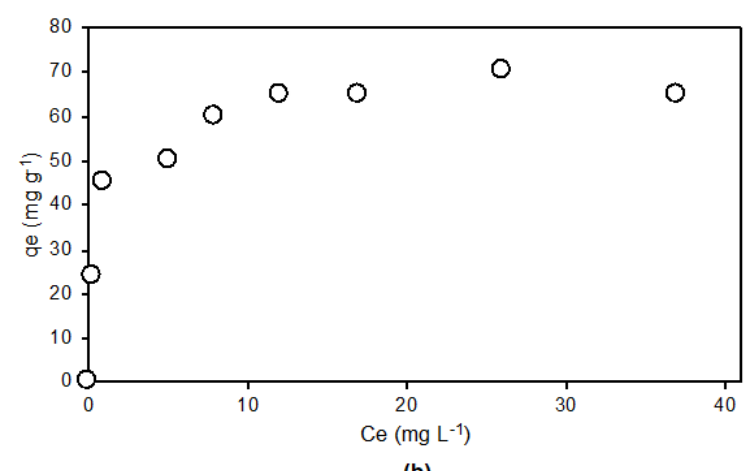

(b)

Figure 4. (a) Effect of adsorption time on the adsorption capability of activated kaolinite material. Mass of the adsorbent $=200 \mathrm{mg}$. Volume of the aqueous solution $=50 \mathrm{~mL}$. [Methylene blue] $=20 \mathrm{mg} \mathrm{L}^{-1}$. Shaking speed $=150 \mathrm{rpm}$. (b) Adsorption isotherm for methylene blue using activated kaolinite material. Mass of the adsorbent $=200 \mathrm{mg}$. Volume of the aqueous solution $=50 \mathrm{~mL}$. Shaking speed $=150 \mathrm{rpm}$. Adsorption time $=30 \mathrm{~min}$. 

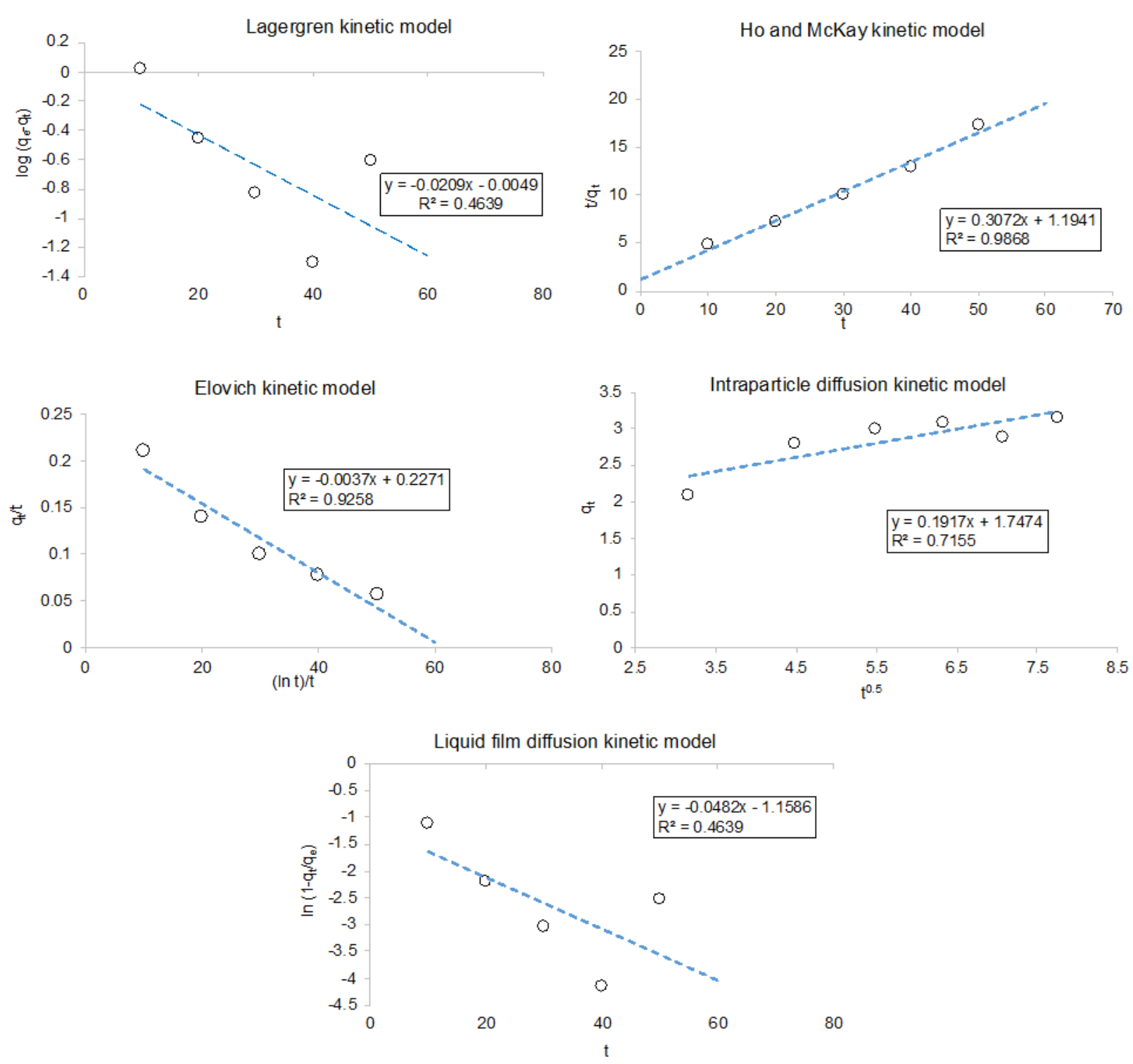

Figure 5. Kinetic models of methylene blue adsorption using activated kaolinite material. Mass of the adsorbent $=200 \mathrm{mg}$. Volume of the aqueous solution $=50 \mathrm{~mL}$. [Methylene blue] $=20 \mathrm{mg} \mathrm{L}^{-1}$. Shaking speed $=150 \mathrm{rpm}$.

0 1) and ( $\left.\begin{array}{lll}2 & 0 & 0\end{array}\right) \mathrm{hkl}$ planes, respectively. From the spectral assignment, the activated kaolinite material was mainly composed of kaolinite crystal phase as previously described [23].

The SEM micrograph of activated kaolinite is shown in Figure 2(a) with a scale bar of $200 \mathrm{~mm}$. The morphology of activated kaolinite material shows agglomerated crystal materials in micrometer size. This morphology supported the XRD data that the activated kaolinite material composed of several crystal phases. The nitrogen adsorption-desorption isotherm plot is shown in Figure 2(b). From the BET calculation, the activated kaolinite material has a surface area of $76.86 \mathrm{~m}^{2} \mathrm{~g}^{-1}$, a pore size of $8.39 \mathrm{~nm}$, and a pore volume of $17.66 \mathrm{~mL} \mathrm{~g}^{-1}$. The activated kaolinite material has a higher surface area, a bigger pore size, and a larger pore volume than the un-activated kaolinite material, i.e. 61.13 $\mathrm{m}^{2} \mathrm{~g}^{-1}, 7.72 \mathrm{~nm}$, and $0.12 \mathrm{~mL} \mathrm{~g}^{-1}$, respectively [15]. Because of that, the activated kaolinite material was further evaluated for methylene blue adsorption.

\subsection{Adsorption of methylene blue using activated kaolinite material}

Before the adsorption experiment, a series of methylene blue standard solution was prepared at 5 , 10,20 , and $30 \mathrm{mg} \mathrm{L}^{-1}$ concentration. The visible spectrum of a series of methylene blue standard solution is shown in Figure 3(a) while Figure 3(b) shows the calibration curve to calculate the 
Tabel 2. Isotherm adsorption model of methylene blue using activated kaolinite material.

\begin{tabular}{llc}
\hline \multicolumn{1}{c}{ Kinetic model } & \multicolumn{1}{c}{ Mathematical equation } & $\mathbf{R}^{2}$ \\
\hline Lagergren & $\log \left(\mathrm{q}_{\mathrm{e}}-\mathrm{q}_{\mathrm{t}}\right)=-0.0209 \mathrm{t}-0.0049$ & 0.4639 \\
Ho-McKay & $\mathrm{t} / \mathrm{q}_{\mathrm{t}}=0.3072 \mathrm{t}+1.1941$ & 0.9868 \\
Elovich & $\mathrm{q}_{\mathrm{t}} / \mathrm{t}=-0.0037(\ln \mathrm{t}) / \mathrm{t}+0.2271$ & 0.9258 \\
Intraparticle diffusion & $\mathrm{q}_{\mathrm{t}}=0.1917 \mathrm{t}^{0.5}+1.7474$ & 0.7155 \\
Liquid film diffusion & $\ln \left(1-\mathrm{q}_{\mathrm{t}} / \mathrm{q}_{\mathrm{e}}\right)=-0.0482 \mathrm{t}-1.1586$ & 0.4639 \\
\hline
\end{tabular}

concentration of methylene blue. Methylene blue has two adsorption signals at 612 and $665 \mathrm{~nm}$ as previously reported. The calibration curve gave the equation of $\mathrm{Abs}=0.0872$ [Methylene blue] +0.004 with $\mathrm{R}^{2}$ value of 0.9944 .

The kinetic study of methylene blue adsorption using activated kaolinite material was evaluated and the results are shown in Figures 4(a) and 5, as well as Table 1. The required time to reach equilibrium was $20 \mathrm{~min}$. From the kinetic models, it was found that the methylene blue adsorption followed Ho and McKay model with an $\mathrm{R}^{2}$ value of 0.9868 . The theoretical $\mathrm{q}_{\mathrm{e}}$ (amount of methylene blue adsorbed per unit of activated kaolinite material) value (3.26 $\mathrm{mg} \mathrm{g}^{-1}$ ) was near to the experimental $\mathrm{q}_{\mathrm{e}}$ value (3.15 $\mathrm{mg} \mathrm{g}^{-1}$ ) demonstrating the validity of Ho and
McKay model in the present study [24].

On the other hand, the adsorption isotherm of methylene blue adsorption was studied and the results are shown in Figures 4(b) and 6, as well as Table 2. The $\mathrm{q}_{\mathrm{e}}$ value was reached a plateau at $\mathrm{Ce}=$ $12 \mathrm{mg} \mathrm{L}^{-1}$. From the adsorption isotherm models, it was found that the methylene blue adsorption followed the Langmuir model with an $\mathrm{R}^{2}$ value of 0.9961. According to the Langmuir model, the maximum adsorption capacity $\left(\mathrm{q}_{\max }\right)$ and Langmuir constant $\left(\mathrm{K}_{\mathrm{L}}\right)$ of $3.40 \mathrm{mg} \mathrm{g}^{-1}$ and $1.36 \mathrm{~L} \mathrm{mg}^{-1}$, respectively. The separation constant $\left(\mathrm{R}_{\mathrm{L}}\right)$ value was 0.035 demonstrating that the adsorption of methylene blue using activated kaolinite material was favorable $\left(0<\mathrm{R}_{\mathrm{L}}<1\right)$ [24].

Table 3 shows the $\mathrm{q}_{\max }$ values of several
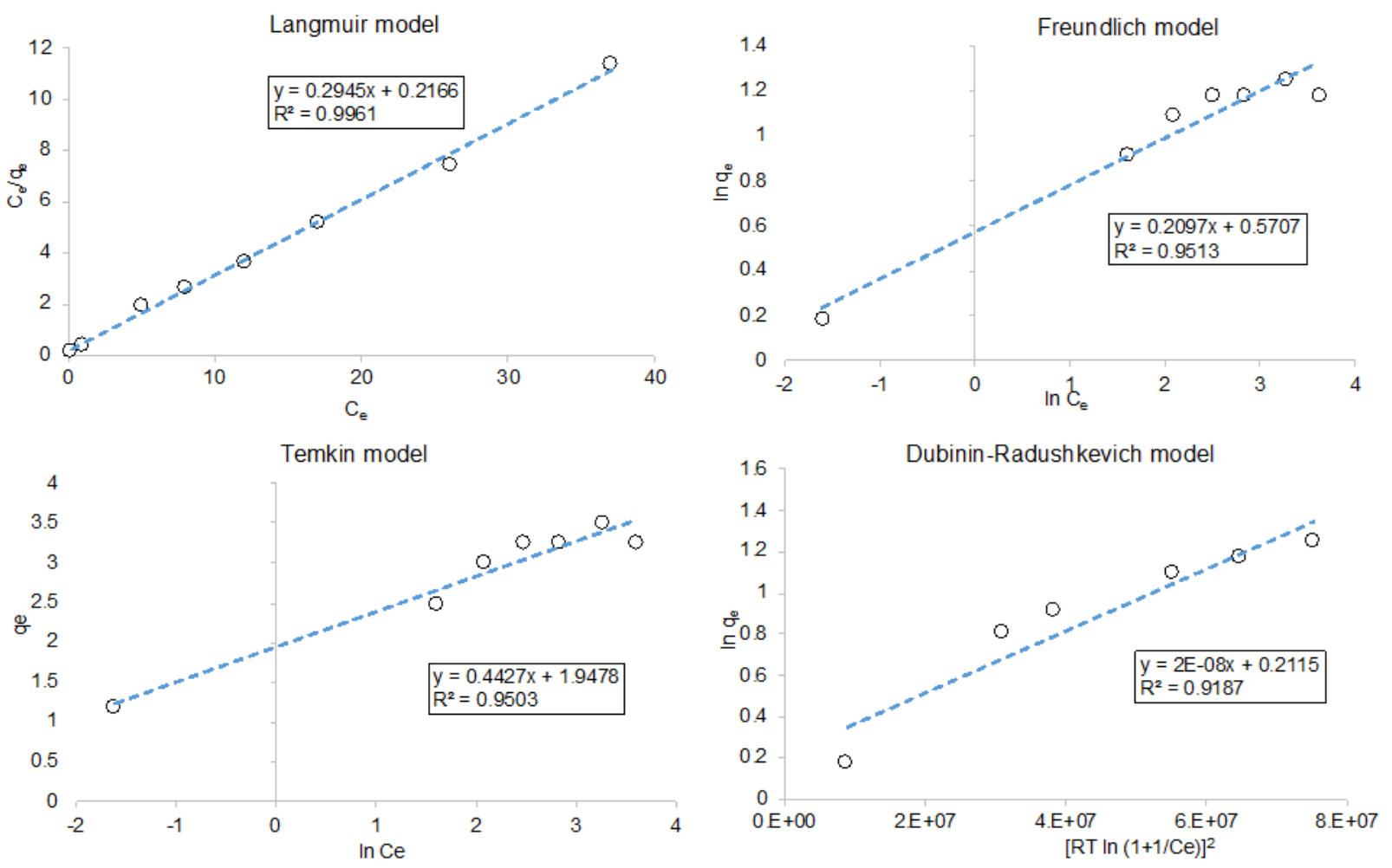

Figure 6. Adsorption isotherm models of methylene blue adsorption using activated kaolinite material. Mass of the adsorbent $=200 \mathrm{mg}$. Volume of the aqueous solution $=50 \mathrm{~mL}$. Shaking speed $=150 \mathrm{rpm}$. Adsorption time $=30 \mathrm{~min}$. 
Tabel 2. Isotherm adsorption model of methylene blue using activated kaolinite material.

\begin{tabular}{llc}
\hline \multicolumn{1}{c}{ Isotherm adsorption model } & \multicolumn{1}{c}{ Mathematical equation } & $\mathbf{R}^{\mathbf{2}}$ \\
\hline Langmuir & $\mathrm{C}_{\mathrm{e}} / \mathrm{q}_{\mathrm{e}}=0.2945 \mathrm{C}_{\mathrm{e}}+0.2166$ & 0.9961 \\
Freundlich & $\ln \mathrm{q}_{\mathrm{e}}=0.2097 \ln \mathrm{C}_{\mathrm{e}}+0.5707$ & 0.9513 \\
Temkin & $\mathrm{q}_{\mathrm{e}}=-0.0037 \ln \mathrm{C}_{\mathrm{e}}+1.9478$ & 0.9503 \\
Dubinin-Radushkevich & $\ln \mathrm{q}_{\mathrm{e}}=2 \times 10^{-8}\left[\mathrm{RT} \ln \left(1+1 / \mathrm{C}_{\mathrm{e}}\right)\right]^{2}+0.2115$ & 0.9187 \\
\hline
\end{tabular}

adsorbent materials. A different source of kaolinite material gave different $\mathrm{q}_{\max }$ values (see Table 3 lines 1-4). This phenomenon may be caused by different geochemical environment and crystal phases. The $\mathrm{q}_{\max }$ value of Wediombo kaolinite was lower than Algerian and Indian kaolinites but still higher than Malaysian kaolinite. Furthermore, the $\mathrm{q}_{\max }$ value of Wediombo kaolinite was higher than other adsorbent materials, such as fly ash, red mud, glass wool, fine ground wheat straw, activated carbons, living biomass, eggshell, chrome sludge, and magnetic nanoparticles, which was remarkable (see Table 3 lines 5-15).

It was reported that clay-based materials consist of tetrahedral silica and octahedral alumina layers with both Bronsted and Lewis acid sites. Sandollah et al. reported methylene blue adsorption on activated kaolinite occurred through an ionexchange reaction [3]. Meanwhile, Rida et al. reported that methylene blue was adsorbed on the activated kaolinite surface through hydrogen bonding and electrostatic interactions [15]. Therefore, the adsorption of methylene blue could happen through either hydrogen bonding or electrostatic interactions as shown in Figure 7. Such a moderate $\mathrm{q}_{\max }$ value $\left(3.40 \mathrm{mg} \mathrm{g}^{-1}\right)$ may be caused by the agglomeration of several crystal phases as shown from the SEM image in Figure 2(a).

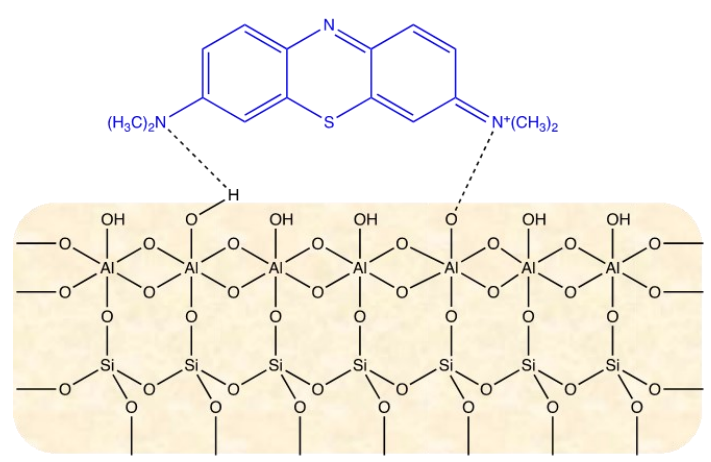

Figure 7. Plausible chemical interactions for methylene blue adsorption on the surface of activated kaolinite material.

\section{CONCLUSIONS}

Activation of Wediombo kaolinite using acidic condition yielded a low-cost activated kaolinite material with efficient adsorption capability for methylene blue removal. The success of the activation process was proved by the FTIR spectrum. The activated kaolinite contains kaolinite, quartz, halloysite, and cristobalite crystal phases as shown from the XRD data. The morphology of activated kaolinite material shows agglomerated crystal materials in micrometer size with high surface area and large pore volume. It was found that the methylene blue adsorption followed Ho and McKay model with $\mathrm{q}_{\mathrm{e}}$ value of $3.15 \mathrm{mg} \mathrm{g}^{-1}$. On the other hand, the adsorption isotherm of methylene blue adsorption followed the Langmuir model with $\mathrm{q}_{\max }, \mathrm{K}_{\mathrm{L}}$, and $\mathrm{R}_{\mathrm{L}}$ values of $3.40 \mathrm{mg} \mathrm{g}^{-1}, 1.36 \mathrm{~L} \mathrm{mg}^{-1}$, and 0.035 , respectively. The $\mathrm{q}_{\max }$ value of Wediombo kaolinite was higher than other adsorbent materials demonstrating that efficient methylene blue removal from the aqueous phase has been successfully achieved. Nevertheless, further modification of the kaolinite material is still required to improve its adsorption ability for a real commercial process.

\section{AUTHOR INFORMATION}

\section{Corresponding Author}

Yehezkiel Steven Kurniawan - Ma Chung Research Center for Photosynthetic Pigments, Universitas Ma Chung, Malang-65151 (Indonesia); D orcid.org/0000-0002-4547-239X

Email: yehezkiel.steven@machung.ac.id

\section{Authors}

Christyowati Primi Sagita - Ma Chung Research Center for Photosynthetic Pigments, Universitas Ma Chung, Malang-65151 
Tabel 3. Maximum adsorption capacities of several adsorbent materials for methylene blue.

\begin{tabular}{lcc}
\hline \multicolumn{1}{c}{ Adsorbent material } & $\mathbf{q}_{\mathbf{m a x}}\left(\mathbf{m g} \mathbf{~ g}^{\mathbf{- 1}}\right)$ & Reference \\
\hline Algerian kaolinite & 13.99 & {$[15]$} \\
Indian kaolinite & 7.59 & {$[25]$} \\
Wediombo kaolinite & 3.40 & Present work \\
Malaysian kaolinite & 1.37 & {$[3]$} \\
Fly ash & 2.85 & {$[26]$} \\
Red mud & 2.49 & {$[27]$} \\
Glass wool & 2.24 & {$[28]$} \\
Fine ground wheat straw & 2.23 & {$[29]$} \\
Almond shell based activated carbon & 1.33 & {$[30]$} \\
Fir wood based activated carbon & 1.21 & {$[31]$} \\
Living biomass & 1.17 & {$[32]$} \\
Corncob based activated carbon & 0.84 & {$[33]$} \\
Eggshell & 0.80 & {$[34]$} \\
Chrome sludge & 0.51 & {$[35]$} \\
Magnetic nanoparticles & 0.20 & {$[36]$} \\
\hline
\end{tabular}

(Indonesia); Department of Industrial Chemistry, Pukyong National University, Busan-48513 (South Korea);

(1D) orcid.org/0000-0002-9626-091X

Limpat Nulandaya - Center for Progressive Materials-Technology and Innovation Park, Pavol Jozef Šafárik University, Kosice-04011 (Slovakia); Institute of Experimental Physics, Slovak Academy of Sciences, Kosice-04001 (Slovakia);

(1) orcid.org/0000-0002-0898-7933

\section{REFERENCES}

[1] G. N. Madapuri, H. N. Azwar, and M. A. Hasyim. (2021). "Estimation of $\mathrm{CO}_{2}$ Absorption, Biomass, and Carbon Deposit the Trees on the Street City of Malang”. Journal of Multidisciplinary Applied Natural Sciences. 1 (1): 18-24. $10.47352 /$ imans.v1i1.5.

[2] J. Jumina, Y. Yasodhara, S. Triono, Y. S. Kurniawan, Y. Priastomo, H. M. Chawla, and N. Kumar. (2021). "Preparation and Evaluation of a-Cellulose Based New Heterogeneous Catalyst for Production of Biodiesel". Journal of Applied Polymer
Science. 138 (2): 49658. 10.1002/app.49658.

[3] N. A. S. M. Sandollah, S. A. I. S. M. Ghazali, W. N. W. Ibrahim, and R. Rusmin. (2020). "Adsorption-Desorption Profile of Methylene Blue Dye on Raw and Acid Activated Kaolinite". Indonesian Journal of Chemistry. 20 (4): 755-765. 10.22146/ijc.43552.

[4] M. Rafatullah, O. Sulaiman, R. Hashim, and A. Ahmad. (2010). "Adsorption of Methylene Blue on Low-Cost Adsorbents: A Review". Journal of Hazardous Materials. 177: 70-80. 10.1016/j.jhazmat.2009.12.047.

[5] D. Pathania, S. Sharma, and P. Singh. (2017). "Removal of Methylene Blue by Adsorption onto Activated Carbon Developed from Ficus carica Bast". Arabian Journal of Chemistry. 10: S1445-S1451. 10.1016/ j.arabjc.2013.04.021.

[6] A. C. Imawan, Y. S. Kurniawan, M. F. Lukman, J. Jumina, T. Triyono, and D. Siswanta. (2018). "Synthesis and Kinetic Study of the Urea Controlled Release Composite Material: Sodium Lignosulfonate from Isolation of Wood Sawdust-Sodium Alginate-Tapioca". Indonesian Journal of Chemistry. 18 (1): 108-115. 10.22146/ ijc.26597. 
[7] H. Awala, E. Leite, L. C. Marcel, G. Clet, R. Retoux, I. Naydenova, and S. Mintova. (2016). "Properties of Methylene Blue in the Presence of Zeolite Nanoparticles". New Journal of Chemistry. 40: 4277-4284. 10.1039/C5NJ02643A.

[8] G. K. Dedzo. (2018). "Kaolinite Clay Mineral Reactivity Improvement through Ionic Liquid Functionalization". Israel Journal of Chemistry. 59 (9): 778-788. ijch.201800130.

[9] R. R. Elmorsi, S. T. El-Wakeel, W. A. S. ElDein, H. R. Lotfy, W. E. Rashwan, M. Nagah, S. A. Shaaban, S. A. S. Ahmed, I. Y. ElSherif, and K. S. A. El-Sherbini. (2019). "Adsorption of Methylene Blue and $\mathrm{Pb}^{2+}$ by using Acid-Activated Posidonia oceanica Waste. Scientific Reports. 9: 3356. 10.1038/ s41598-019-39945-1.

[10] Y. Liu, J. Jia, T. Gao, X. Wang, J. Yu, D. Wu, and F. Li. (2020). "Rapid, Selective Adsorption of Methylene Blue from Aqueous Solution by Durable Nanofibrous Membranes". Journal of Chemical \& Engineering Data. 65 (8): 3998-4008. 10.1021/acs.jced.0c00318.

[11] Y. Kuang, X. Zhang, and S. Zhou. (2020). "Adsorption of Methylene Blue in Water onto Activated Carbon by Surfactant Modification". Water. 12: 587. 10.3390/ w12020587.

[12] O. S. Bayomie, H. Kandeel, T. Shoeib, H. Yang, N. Youssed, and M. M. H. El-Sayed. (2020). "Novel Approach for Effective Removal of Methylene Blue Dye from Water using Fava Been Peel Waste". Scientific Reports. 10: 7824. 10.1038/s41598-02064727-5.

[13] H. Han, M. K. Rafiq, T. Zhou, R. Xu, O. Masek, and X. Li. (2019). "A Critical Review of Clay-Based Composites with Enhanced Adsorption Performance for Metal and Organic Pollutants". Journal of Hazardous Materials. 369: 780-796. $\quad$ 10.1016/ j.jhazmat.2019.02.003.

[14] Y. S. Kurniawan, K. T. A. Priyangga, P. A. Krisbiantoro, and A. C. Imawan. (2021). "Green Chemistry Influences in Organic Synthesis: A Review". Journal of
Multidisciplinary Applied Natural Sciences. 1 (1): 1-12. 10.47352/jmans.v1i1.2.

[15] K. Rida, S. Bouraoui, and S. Hadnine. (2013). "Adsorption of Methylene Blue from Aqueous Solution by Kaolin and Zeolite". Applied Clay Science. 83-84: 99-105. 10.1016/j.clay.2013.08.015.

[16] K. Mukherjee, A. Kedia, K. J. Rao, S. Dhir, and S. Paria. (2015). "Adsorption Enhancement of Methylene Blue Dye at Kaolinite Clay-Water Interface Influenced by Electrolyte Solutions". RSC Advances. 5: 30654-30659. 10.1039/C5RA03534A.

[17] Q. Zhang, Y. Zhang, J. Chen, and Q. Liu. (2019). "Hierarchical Structure Kaolinite Nanospheres with Remarkably Enhanced Adsorption Properties for Methylene Blue". Nanoscale Research Letters. 14: 109. 10.1186/s11671-019-2934-x.

[18] G. Hartono and S. Bronto. (2007). "Asal-Usul Pembentukan Gunung Batur di Daerah Wediombo, Gunungkidul, Yogyakarta". Jurnal Geologi Indonesia. 2: 143-158.

[19] Y. S. Kurniawan, K. Thomas, H. Hendra, J. Jumina, and T. D. Wahyuningsih. (2021). "Green Synthesis of Alkyl 8-(2-butyl-5-octyl1,3-dioxolan-4-yl)octanoate as Potential Biolubricants from Used Frying Oil". Science Asia. 47: $10 . \quad$ 10.2306/scienceasia15131874.2021.010.

[20] M. G. Valles, P. Alfonso, S. Martinez, and N. Roca. (2020). "Mineralogical and Thermal Characterization of Kaolinitic Clays from Terra Alta (Catalonia, Spain)". Minerals. 10: 142. 10.3390.min 10020142 .

[21] B. J. Saikia and G. Partasarathy. (2010). "Fourier Transform Infrared Spectroscopic Characterization of Kaolinite from Assam and Meghalaya, Northeastern India". Journal of Modern Physics. 1: 206-210. 10.4236/ jmp.2010.14031.

[22] T. Thiebault. (2019). "Raw and Modified Clays and Clay Minerals for the Removal of harmaceutical Products from Aqueous Solutions: State of the Art and Future Perspectives". Critical Reviews in Environmental Science and Technology. 50 (14):

1451-1514. 10.1080/10643389.2019.1663065. 
[23] I. Daou, G. L. Lecomte-Nana, N. TessierDoyen, C. Peyratout, M. F. Gonon, and R. Guinebretiere. (2020). "Probing the Dehydroxylation of Kaolinite and Halloysite by In Situ High Temperature X-ray Diffraction". Minerals. 10: 480. 10.3390/ $\min 10050480$.

[24] J. Jumina, Y. Priastomo, H. R. Setiawan, M. Mutmainah, Y. S. Kurniawan, and K. Ohto. (2020). "Simultaneous Removal of Lead(II), Chromium(III) and Copper(II) Heavy Metal Ions through an Adsorption Process using CPhenylcalix[4]pyrogallolarene Material". Journal of Environmental Chemical Engineering. 8: 103971. $\quad \underline{10.1016 /}$ j.jece.2020.103971.

[25] D. Ghosh and K. G. Bhattacharyya. (2002). "Adsorption of Methylene Blue on Kaolinite". Applied Clay Science. 20: 295-300. 10.1016/ S0169-1317(01)00081-3.

[26] K. V. Kumar. (2002). "Adsorption Isotherm for Basic Dye onto Low Cost Adsorbents". Research Journal of Chemistry and Environment. 6: 61-65.

[27] S. Wang, Y. Boyjoo, and A. A. Choueib. (2005). "A Comparative Study of Dye Removal using Fly Ash Treated by Different Methods". Chemosphere. 60: 1401-1407. 10.1016/j.chemosphere.2005.01.091.

[28] S. Chakrabarti and B. K. Dutta. (2005). "Note on the Adsorption and Diffusion of Methylene Blue in Glass Fibers". Journal of Colloid and Interface Science. 286: 807-811. 10.1016/ j.jcis.2005.01.035.

[29] F. A. Batzias, D. K. Sidiras, E. Schroeder, and C. Weber. (2009). "Simulation of Dye Adsorption on Hydrolyzed Wheat Straw in Batch and Fixed-Bed Systems". Chemical Engineering Journal. 148: 459-472. 10.1016/ j.cej.2008.09.025.

[30] A. Aygun, S. Yenisoy-Karakas, and I. Duman. (2003). "Production of Granular Activated Carbon from Fruit Stones and Nutshells and Evaluation of Their Physical, Chemical and Adsorption Properties". Microporous and Mesoporous Materials. 66: 189-195. 10.1016/j.micromeso.2003.08.028.

[31] F. C. Wu and R. L. Tseng. (2008). "High Adsorption Capacity $\mathrm{NaOH}$-Activated Carbon for Dye Removal from Aqueous Solution". Journal of Hazardous Materials. 152: 12561267. 10.1016/j.jhazmat.2007.07.109.

[32] Y. Fu and T. Viraraghavan. (2000). "Removal of A Dye from An Aqueous Solution by the Fungus Aspergillus niger". Water Quality Research Journal. 35: 95-111. 10.2166/ warj.2000.006.

[33] R. L. Tseng, S. K. Tseng, and F. C. Wu. (2006). "Preparation of High Surface Area Carbons from Corncob using $\mathrm{KOH}$ Combined with $\mathrm{CO}_{2}$ Gasification for the Adsorption of Dyes and Phenols from Water". Colloids and Surfaces A: Physicochemical and Engineering Aspects. 279: 69-78. $\quad \underline{10.1016 /}$ j.colsurfa.2005.12.042.

[34] W. T. Tsai, J. M. Yang, C. W. Lai, Y. H. Cheng, C. C. Lin, and C. W. Yeh. (2006). "Characterization and Adsorption Properties of Eggshells and Eggshell Membrane". Bioresource Technology. 97: 488-493. 10.1016/j.biortech.2005.02.050.

[35] C. Lee, K. Low, and S. Chow. (1996). "Chrome Sludge as An Adsorbent for Color Removal”. Environmental Technology. 17: 1023-1028. 10.1080/09593331708616471.

[36] S. Y. Mak, and D. H. Chen. (2004). "Fast Adsorption of Methylene Blue on Polyacrylic Acid-Bound Iron Oxide Magnetic Nanoparticles". Dyes and Pigments. 61: 9398. 10.1016/j.dyepig.2003.10.008. 